\title{
DEVELOPING WILDLIFE RELATED TOURISM FOR GAME MANAGEMENT SUSTAINABILITY IN GEORGIA
}

\author{
Suzana Đorđević - Milošević*, \\ Jelena Milovanović, \\ Ljubiša Đorđev
}

Singidunum University, Belgrade, Serbia

\begin{abstract}
:
Identifying true potentials for sustainable wildlife management starts with the confirmation of the disturbed status of the wildlife that requires changes in its management. Selecting measures to reverse degradation comes with understanding its evolution up to the appearance of the imbalance in exploitation. History of the human-wildlife relations helps the selection of critical points for intervention and the frames of favorable activities. In the case of this research, favorable activities are all those which can play a role in "a bite" for local communities to get involved in designing and implementing a new model of sustainable wildlife management. This paper presents the results of an exercise of exploring potentials for introducing wildlife-related economic activities into local communities in the Uravi Area under the Caucasus, Georgia. The one was selected to contribute to modeling local community involvement in the evolution towards improved wildlife management in Georgia. Both invasive and non-invasive utilization of the game through developing tourist products are explored as the potential to firmly substantiate wildlife management advancement. Natural and cultural heritages are both employed to design a few perspective wildlife related tourist products suitable for Georgia.
\end{abstract}

Keywords:

wildlife management, hunting tourism, community driven action, Georgia.

\section{INTRODUCTION}

It is generally believed that the great demand for game and fish, the inefficient approaches in administration to regulate wildlife management and use and the loss of wildlife habitats have led to significant depletion of game and fish stocks in Georgia. The Government of Georgia therefore took an appropriate approach to solve the problem by establishing a new, sustainable wildlife resources management system (Bregadze et al., 2018, Czudek, 2006). Promoting sustainable hunting and fishing activities by involving the rural population in wildlife resources management and use should be employed to contribute to income diversification of rural households and poverty alleviation which should decrease pressure of game and fish resources. Working with local communities seems not just inevitable, but a key for mitigating number of risks as much as an opportunity to contribute to rural livelihoods, yet it will need much more than just defining and imposing new rules.
Correspondence:

Suzana Đorđević - Milošević

e-mail:

sdjordjevicmilosevic@singidunum.ac.rs 
Simple copy-paste of solutions from other countries was out of question. One of the ideas how to get on board local communities to support change and take active participation in them, was introducing the wildlife related tourism into local rural economy (Martytin-Delgado et al., 2020). This paper should contribute to transforming local communities in Georgia into business partners by introducing tourism development which is seen as the most effective way to achieve sustainable wildlife management while contributing to rural development.

\section{LITERATURE REVIEW}

Human activities are destroying biodiversity so rapidly, that biodiversity loss also became a development issue (Kikvidze \& Tevzadze, 2015). The global biodiversity crisis is hitting the poorest communities first and hardest because they can ill-afford to 'buy in' biodiversity's previously-free goods and services (UNECE, 2019, Roe et al.., 2019). The old approach to biodiversity conservation called "fortress conservation" (Breitenmsoer et al. 2010, Whande, 2007) is outdated although still survives in many countries. In the 1980s, the first attempts were made to preserve natural habitats and wildlife through involvement of local communities in the management of these resources and ever since professionals worldwide seek how to create a better synthesis between conservation and development to upgrade sustainable management of wildlife populations based on local communities (Tynnerson, 2009). The resulting type of management, called Local Community-Based Natural Resource Management (CBNRM), foresees the reallocation of the authority over the resources from the immediate nature to local people, comprising such as game, wood and other wildlife related products and services. Incentives to influence the behavior and interests of the inhabitants of rural areas are also needed to lead to the transformation of the local community into a community-based conservator. Major institutional reforms and significant changes in the distribution of power were required. CBNRM implies that local community is getting right to use wildlife resources to create new jobs within various services - starting from the very conservation of nature through income from animal husbandry, which is set to endanger wildlife, but also from newly created activities such as tourism, photography and hunting activities (Stone, 2006). For areas where wildlife is managed by the local community, tourism is a land use option that is likely to provide the most revenue. Examples of this claim are numerous, especially in Africa where the concept first came to life (NASCO, 2015, Sakal \& Moyo, 2017, Cooney et al., 2018, Maliasili, 2011, Malembo, 2011). To select tourism activities to be encouraged and design their suitable value chains to fit within the local rural economy for maximizing benefits, respective area should be carefully assessed. Available natural and human resources would frame it, but also the economy in place (possible accommodation, catering and other services supply chains). Cultural heritage might appear crucial to create innovative and competitive tourism products in a traditional countryside.

\section{METHODOLOGY}

The paper presents an exercise of exploring potentials for introducing wildlife-related economic activities into local communities in the Uravi Area under the Caucasus, Georgia. Research included field and desk work for exploring rural cultures and history of wildlife management in Georgia. Semi-structured interviews were used to assess the knowledge and experiences of local population of Uravi area, institutions responsible for wildlife management and law enforcement, Georgian entrepreneurs - wildlife reserves (farms) managers, hunters civil societies dealing with socio-economic issues in local community and environmental civil society organizations, local authorities in Racha Region and central Government of Georgia (new established wildlife agency). Both invasive and non-invasive utilization of the game through developing tourist products were explored as the potential to firmly substantiate wildlife management advancement. Data on natural and cultural heritages are both employed to design a few perspective wildlife related tourist products suitable for the pilot region. These were selected to contribute to modeling local community involvement in the evolution towards improved wildlife management in Georgia. 


\section{RESULTS AND DISCUSSION}

Hunting and fishing contribution to food and nutrition security in rural areas is considerable, but in Georgia its importance goes far beyond an economic activity safeguarding food. It is the part of Georgian valuable intangible culture. There is a huge demand for hunting and fishing, particularly in rural areas, sometimes following specific cultural traditions, which are deeply rooted in local communities. Reportedly, many rural men possess a gun and do hunting as a hobby. Hunting and fishing and the culture developed around them could be also seen as the tourist factor of enormous importance for diversifying rural economies, and therefore a precious resource for the rural development. One of the specific aspects of the traditional hunting was explained to create options for some innovative economic activities related to wildlife - falconry (CG, 2019).

\section{Falconry}

In the mid-sixties this tradition began to revive representing huge opportunity for tourism of special interest as much as production and training of raptors for protection services (defense of air space from birds and rodents on airports, industrial complexes, agriculture etc.) (Sandor, 2015, Abuladze, 2012). The falconry is considered as a national tradition, interlined in lifestyle of the local people. Images of the scenes of falcon aided hunting can be seen at archeological artifact kept in Georgian museums. Especially, noble people of the country were involved in that kind of hunting in medieval times. Even all the families were brought from countryside to the estates of rich and noble people with the task to take care of numerous falcons kept there. The interest for the falconry in this Caucasian country was also presented in the notes of French traveling writer from XVII Century (Van Maanen et al., 2001).

At the beginning of the $20^{\text {th }}$ century, even the talking about falconry was strictly forbidden in Georgia. That was the case up to the period of mid 1960-es, when quietly falconry started to appear again. It becomes a branch of Association of hunters and fishermen, and formally named as Falconry department, but from the socialistic period there are very poor data about hunting campaigns organized using raptor birds (Sandor et al., 2017). There are only some traces from that period which indicate small number of people who were trying to sell smuggled, trained raptor birds. In the contemporary world there is big demand for falcons and other birds which can hunt the prey for human. That is especially the case in the counties rich in oil, such Arab countries are. There exists social class of well-off people who highly appreciate hunting with raptor birds, and who can afford to organize such hunting activities. That can be significant opportunity for Georgian raptor breeders, to export their birds, but there are some limitations which must be observed. International legislation set the ban to the trade of birds born in the wilderness. The only birds which can be the object of trade are those which were born in captivity. On the other hand, for the guests from the Arab countries, and for the other passion able hunters, who can afford that, jackal hunting can be organized as a kind of hunting tourism. That kind of hunting with raptor birds requires extremely large birds (eagles), and it is favorable because it provides significant amount of money from tourists, who can afford expensive organization of that kind of hunting, and on the other hand it can be helpful for the control of the number of jackals as predators.

There are some more benefits obtained by the raising predator birds and by their conservation in the open nature. Some of them are also vultures. Vultures are very useful kind of birds in the nature. They purify nature, by removing the carcasses of dead animals. Besides, some of raptor bird species can be trained to keep some special areas free of nuisance species. That means to keep airports free of pigeons, seagulls and some other species which could harm aircrafts landing and taking off from these airports.

\section{Georgian wildlife in mythology}

Georgian mythology related to wildlife was explored to draw some lessons about the mitigating risks of overuse. In Georgia, population was always respecting nature (Lindpere, 2013). Many customs come from the nature worship roots. Mountains and woods are still concerned sacred. Hunting and fisheries traditions in Georgia relate to Georgian mythology in large extent. There are a lot of mythical creatures related to hunting and fisheries. 
What could be noted is that certain rules in hunting were imposed through these myths, enforcing unwritten laws about sustainable wildlife management, meaning that Georgians are not poachers by default, as some analysts tend easily to conclude. On the contrary, Georgian culture of traditional hunting is very sophisticated. The question is how to impose similar rules in modern times, after decades of socio-economic hardships, and follow trend of non-violent modern law enforcement by using awareness rising in combination with financial punishments. Whatever solution is finally selected it's good to know the evolution of hunting culture which one can learn from historical sources and modern ethnology. Ethno-psychology is also a key to successful changes of communities on their road to sustainability. Main stories from literature about myths related to hunting are provided to put more light on historical relation of Georgians with their wildlife.

One of the most popular characters in Georgian mythology is Dali, who is considered as a goddess of hunting. In the mythology, she is presented as a very pretty woman with blond hair and extremely bright skin. In the many of mythology scenes she is depicted together with a herd of ibex, situated in the mountains, on high altitudes. Her main goal in the mythology is to protect the nature and creatures living there. Reportedly, during the hunting campaign, Dali makes special relation with hunter. According those stories, hunter is not allowed to tell anyone about that relation. If he breaks that rule, he, together with his hunting dogs, could be punished very strictly, with dead penalty carried out by petrification (Dzagnidze, 2017). All the way the hunter observes the rules set by Dali, those about protection of nature and wildlife, and hunt only small number of game, just needed for him and his family to survive, Dali is even willing to help the hunter to catch his prey. After the successful hunting, hunter has obligation to leave some parts of the game body in the nature, as a sign of gratitude to Dali, for her help in the hunting campaign. That sharing of the benefit in the mythology stories can also be the motivation for contemporary local communities who are dealing with hunting tourism, to share benefits obtained that way with state, which is, according to the law in Georgia, the owner of all the wildlife.

Besides Dali, in Georgian mythology and other stories, there are some more pre-Christian gods and goddesses connected with nature. There is Apsat, presented as the creature with supernatural powers, who is protector of all birds, and the animals who do not consume meat. Master of all the wolves, in some mythological stories is Mambery. There is also the creature which resembles mermaids from European mythology. She looks like half women and half fish. Her name in the mythology is Tskarishdida. In these mythological stories it can be noticed that many of mystical creatures in them are women. Their supernatural powers provide them to punish persons who do not respect nature and do harm to it. That indicates the position of women in society, as protectors of family, environment and other values for human society.

One of semi-gods depicted in Georgian mythology is Ochopintre. He is described as a creature living in the woods and also on cliffs of high altitude. His head resembles goats head, and he also has horns like goat. He assists goddess Dali in taking care of animals, especially deer game. There are more of these supernatural creatures in Georgian mythology. Some of them are positive, and some negative characters. Some of negative characters of that mythology are Matsil and Chukchi. Matsil is an obscure spirit known as underground creature, who tortures hunters and other people whom he finds in the forest. Chukchi according the legends likes to walk along the forests and to frighten humans whom he finds there, especially hunters. Also, according to the legends, Chukchi fell in love with goddess Tkashi-Mapa, but he was refused by her. Then he tried to catch the goddess, and hunters always helped the lady with superpowers to keep away from Chukchi. In the legends, there is also the famous hunting dog appearing in the stories about goddess Dali and other mythological creatures. The dog's name is Q'ursha, and in mythology he is presented as positive character.

Georgian hunters believe that they must observe some hunter rituals. One of them is that the hunter, getting to hunt from his home, should leave his home early in the morning, before daylights. When he arrives to the hunting grounds, he has to light little fire there and to say a hunter's prayer on the spot. The prayer is dedicated to goddess Dali and to the spirit of Apsat. Speaking among themselves hunters of some Georgian regions, up to the two centuries ago, were using, for the other people unknown, words as names of animal species. For example, for chamois game they were using the word "psit" (Tuite, 2006). They believed that if they were using the ordinary name, like chamois, they would not have good luck in their hunting campaign at that day.

Two examples of wildlife related tourist products value chains, one for edutainment and one for atavistic hunting, are provided as a suggestion for using rich cultural heritage to develop tourism in the pilot area and in Georgia in general. 


\section{Edutainment as a noninvasive activity related to wildlife}

The national heritage of Georgian people associated with animals is very favorable for making nonmaterial tourist attractions. It can be very good foundation to create edutainment tourist arrangements. That noninvasive kind of human activities related to wildlife can diminish classical demand for the products originating from wildlife. Edutainment, as an important tourist activity, represents the set of activities connected with wildlife. In large scales, edutainment is a combination of entertainment and education. Activities are focused to wildlife and its environment. There is also present excitement of discovery, when tourists follow the footsteps of wild animals, when they find the game groups or individuals in the nature. Also, visitors will be able to research relation of people of local communities to wildlife living in their environment. Students of the different schools will be able to analyze relationship between humans and wildlife at that occasion. This kind of tourism can be a significant factor for development of rural areas in Georgia and their local communities. Tourists are those who will have the freedom to choose the area and local communities which they will visit. Because of that, locals will have to analyze very carefully what they can offer to the clients. The offer should be so attractive for different kind of people, with the purpose to bring them to the spot and by buying the services to improve economy of these communities, income of the state, and nature conservation. There are some special niches of the tourists who can be attracted with the offer, and locals have to take care of that and find and target them. Valuable natural and cultural heritage of Georgia should be a good reason for many of people to attract tourists to many of picturesque areas in the country. One of the advantages of this kind of tourism is that the organizers can collect two or more benefits and present it in one tourist arrangement. All of that can provide employment for large number of people of different professions. This kind of tourism must be covered by the workers with various skills. In the most of cases, they must be younger, well-trained people, but also older with some knowledge about tradition of the country and the specific area. Also, people who are familiar with nature and who can explain to tourists how to survive in the nature. There should be hired locals with good cooking skills, who would prepare food specialties typical for that region. Extremely important factor which should contribute to the effort of all local communities to be successful in edutainment business is positive attitude and involvement of all the people from the communities. Coordinating wildlife related edutainment, alongside hunting activities to react to a hunter's family various necessities, can assist client with encountering total fulfillment and remain longer as a tourist.

\section{Atavistic hunting}

The idea of fair chase is the bedrock of hunting ethics. Fair chase implies kind of hunting, which is allowing game a chance to get away (while it does not matter if hunter is using a bow, rifle, bow or any other kind of weapon (Booth and Chardonnet, 2015). In this respect some of atavistic chasing strategies are viewed as appropriate or even respectable these days since they do not connect with contemporary techniques of certain hunt which nowadays are not common. Between the most refreshing, in most recent couple of many years, are bow hunting and hunting with help of winged creatures of prey. Atavistic hunting is related to a number of methods and ceremonies actualized in history by people to catch or execute animals for food, clothes, or different items.

Atavistic hunting requires commitment of local specialists to deliver gear which, once upon a time, was customarily utilized. On the off chance that educated specialists do not exist in the district, commitment of specialists from other regions could be required. These occupations can give extra work of experts of making bows, knifes, gear for horses and raptor birds for falconry. On the off chance, that bow hunting is the situation, hunters are regularly accompanying their own advanced bows and bolts and other hardware, while they have simply need to receive managing. Once in a while likewise capturing or video shooting would be mentioned, and obviously food, accommodation and transport. Host should lead all customs, and for the hunting, about to start, gives composed rules or even video instructional activities. Likewise, customary garments could be a resource for making the offer more alluring, allowing the chance to connect more individuals from the local community. 
If there should be an occurrence of hunting with birds of prey, hunter may have his own prepared feathered creature, or even come to acquire training for its young, winged animal. All the more regularly, hunters are coming to hunt or to observe hunting with birds controlled by the host to appreciate hunting and additionally purchasing fledgling. That could be alluring for both sides - hunters and local communities and people with abilities to develop and prepare assorted types of raptor birds. Obviously, both these activities, hunting and exchanging these creatures, must obey the severe public laws and peaceful accords, for example, CITES (the Convention on International Trade in Endangered Species of Wild Fauna and Flora - multilateral agreement to ensure imperiled plants and animals) and CBD (The Convention on Biological Diversity). These guidelines permit utilization of just birds born in imprisonment, while getting of wild birds isn't permitted.

\section{Mainstreaming SDGs into new wildlife management system}

An attempt was made to explain mainstreaming of sustainable development goals into new wildlife management system. Considering the financial circumstance in the pilot region and basic of accomplishing maximum as could be expected compromise between wildlife protection and local community interests, further policy/ law suggestions supporting future wildlife management system in the Caucasian country will be introduced in connection with the Sustainable Development Goals (SDGs). Most importantly, no strategy or a legitimate frame referring to the wildlife population control ought to be presented in they will disregard the successful lives and jobs of the people of local community. On the contrary, it ought to add to improving prosperity of local communities. Policy frameworks made at national level, just like those created at local and global level, ought to be founded as favorable to poor and gender orientation delicate improvement methodologies. Social agreement ought to be foundation for its finishing shape.

Georgia isn't the country which is fundamentally battling to end hunger, accomplishing Sustainable Development Goal 2 (SDG 2) which is not only elimination of hunger, but also about the feasible food security, woodland biological systems administration, hunting should be considered from this viewpoint as well. Feasibility of food production of small farmers, specifically female, indigenous people groups, livestock farmers, hunters and fishers in local communities, means that those people should have free access to the resources that they need for their production. That also implies favorable ecosystem maintenance which requires that the wildlife management policy should be carried out properly.

That must be molded to advance access and reasonable and impartial sharing of advantages emerging from their use as much as the information, money related administrations, markets and open doors for esteem expansion and non-ranch work dependent on wildlife resources.

Guaranteeing the achievement of preservation and rebuilding incorporate feasible utilization of a wide range of ecosystems, which includes Georgian wildlife habitats, particularly terrestrial and inland freshwater biological systems and their management. This extraordinarily recommends woodlands, wetlands, mountains and dry lands of Georgia, which are nowadays under the hard pressure, mostly because of financial difficulties of people living in the countryside. The solution which should be brought with new management system ought to be in accordance with the taken commitments for nature conservation according international agreements. Policy and legislation edges ought to be modernized, with the purpose to provide sustainable management of forest resources, to end poaching, to reestablish depleted habitats and game and fish populations. In the chosen pilot area, this is identified with protection of mountain ecosystems, including biodiversity, to improve their ability to give benefits that are basic to economical turn of events. It ought to prevent annihilation of endangered species, and to provide sustainable management for the species whose populations are stable, and in that way to enable economic benefits for local communities who would take good care of them, and would responsibly use those wildlife resources.

\section{Community led development as a prerequisite to implement new wildlife management system}

Having SDG Goals as a primary concern, yet essentially needs of local inhabitants, wildlife management system which should be set as innovation ought to be planned with full straightforwardness and cooperation of local communities. Making critical move to end poaching and trade of protected species of plants and animals, taking action to reveal the market of wild animals' illegal products, should be carried out at the same time. 
It must be a partnership between all members of local community on one side, and the Government on the other. That partnership should consider equal sharing of the benefits between all partners. Consequently, just after the new strategy/lawful edges for wildlife management are set on the national level, the management of ecological system and biodiversity values ought to be incorporated into the national and local planning, as well as improvement measures, poverty decrease procedures, and records as the Goal 15 of the SDG anticipate.

After the experience obtained while cooperating with countryside communities in the pilot area, it can be suggested that the best approach is to keep working on the integration process, business development plans for local community, considering environmental objectives. The responsibility for making these plans, in the future, should fully be taken by the local community.

This methodology should make improvement of the local community living standard, and to conserve natural resources simultaneously, with substantially more prescient accomplishment than the other methodologies. In purpose to make activities connected to designing and caring out new wildlife management system, completely suitable, they must include as many participants as possible.

It is important to establish the region-based development approach and to introduce the process of rural development. This new wildlife management approach should only provoke the beginning of the process in the regions and areas where it did not start yet.

It is not possible to carry out sustainable wildlife management in particular area if it is not combined with the similar sort of its general rural development model. Introduction of the new wildlife management may be difficult if local community is not keen on it, so it is least demanding when community economy is frail, and community search for general development help. Better developed areas ought to follow positive experience of less developed ones.

Starting with planning of the sustainable local development is operation with group of subjects participating in it (Moqanaki et al., 2016, Leong \& Decker, 2007). It requires many mandatory activities. Operation demands local community's integration on regional level - local action groups of EU LEADER type. That will help local communities to realize that they have the power to make decisions how they will develop themselves. However, they will also experience responsibility for their social and economic situation. The communities must bear in their minds that they are managing very valuable common good, which is precious. With the purpose to avoid any misconceptions, it is necessary to clarify with local communities what are rights and obligations of the Government, and what of local community, about wildlife, habitat and benefits obtained from them.

EU LEADER type activities were recommended as the appropriate frame for setting up cooperation for supportable wildlife management. Expanding human and social capital for making local community to take place in sharing profit of the new sustainable wildlife management is very important. Encouraging local communities to struggle with bad wildlife management practices and poaching was associated with the battle to offer solid help to rural development by using area based development approach instead of establishing single system for sustainable wildlife management in entire Georgia which is isolated from rural development.

Local action groups (LAGs) of the EU LEADER Program are suitable because they give opportunity to persons who took part in them to learn while they practice their activities (learning by doing). The local action groups are one of the most productive instruments for wildlife areas in the future.

One of the rear hardships about them can be the fact that well demarcated hunting areas correspond to the natural boundaries. On the other hand, areas in which local action groups are usually formed are not determined by geographical objects as their borders, but they have administrative borders.

Process of gathering smaller administrative areas in the bigger territory provides all of them with sharing natural resources, which give solution to mentioned problem. That process enables adaptation of the policy of hunting area designing to correlate with administrative borders of local communities, which were formed as LAG territories. Areas where there are present frequent human activities should be demarcated and excluded from the territory of hunting grounds. Hunters' activities with hunting arms should be forbidden within the perimeter of $200 \mathrm{~m}$ from lonely households or small villages in the countryside. Urban settlements should be surrounded with $1000 \mathrm{~m}$ wide buffer zone. Hunting ground management authorities should be in charge of occasional interventions in the buffer zones. That means the area of the buffer zone should not be used for shutting, but it has to be managed like all the other parts of the hunting grounds, measures of protection and support to the wildlife should be applied there. 
Sport fishing ought to be permitted in places suitable for recreation, where safe waste management is provided.

Forming LAGs also bring public-private partnerships. Those partnerships can be helpful for including human and financial resources to improve natural resources management.

International stakeholders could be included as financial donors who might support planned activities and in large scale to improve capacities of local communities to conserve, monitor and sustainably use natural resources. The stakeholders would be motivated to take action by creating high-quality rural development plans, which should be developed by LAGs.

\section{CONCLUSIONS}

Setting sustainable tourism around wildlife in Georgia is much more than a matter of available wildlife. It is also a question of its cultural heritage employment. Whole presented heritage is extremely interesting for creating non-consumptive tourist activities related to the wildlife, but also understanding local community limits and opportunities for sustainable wildlife management. Cultural heritage compiled with existing rural economy can help creating valuable sustainable wildlife related tourism products in the area of edutainment and atavistic hunting. Promoting such tourist products might be a good strategy for decreasing pressure on animals imposed by the consumptive types of related tourism such as hunting. Capacity building for local communities to establish LEADER type partnerships and to officials to provide technical support and law enforcement as well as strong institutional support is necessary for wildlife related tourism development and implementation in Georgia.

\section{ACKNOWLEDGMENT}

The research was conducted based on TCP/GEO/3603 Project Agreement and the Agreement of Cooperation No. 0801-417/1 (21/03/2019).

\section{REFERENCES}

Abuladze, A. (2012). A preliminary overview of raptor monitoring in Georgia, Acrocephalus no 33 289-292, Retrieved October $20^{\text {th }}, 2020$ from http://www.eurapmon.net/sites/default/files/eurapmon_acrocephalus_013_georgia.pdf

Booth V., Chardonnet P. (2015). Guidelines for improving the administration of sustainable hunting in subSaharan Africa, FAO sub-Regional Office for Southern Africa, Harare (Zimbabwe), Retrieved November $21^{\text {st }}, 2020$ from http://www.fao.org/3/a-bo583e.pdf

Bregadze, J., Shukakidze, N., \& Vashakmadze, K. (2018). Georgean tourism in figures. Tbilisi, Georgia: Georgian national tourism administration. Retrieved October $20^{\text {th }}$, 2020 from https://gnta.ge/wp-content/ uploads/2018/07/2017-ENG.pdf

Breitenmsoer, U., Shavgulidze, I., Askerov, E., Khorozyan, I., Farhadinia, M., Can, E., Bilgin, C., \& Zazanashvili, N. (2010). Leopard conservation in the Caucasus. Cat news No 53, Autumn 2010. IUCN - The World Conservation Union. Retrieved October $20^{\text {th }}, 2020$ from https://www.researchgate.net/publication/269399152_Leopard_conservation_in_the_Caucasus

CG (Concord group) (2019). Hunting tour in Georgia, Caucasus - Falconry tour, Retrieved October $20^{\text {th }}, 2020$ from http://www.concordtravel.ge/portal/alias_concordtravel/lang_en/tabid_1816/default.aspx

Cooney, R., Roe, D., Dublin, H. \& Booker, F. (2018). Wildlife, Wild Livelihoods: Involving Communities in Sustainable Wildlife Management and Combatting the Illegal Wildlife Trade, United Nations Environment Programme, Nairobi, Kenya, retrieved September 6 ${ }^{\text {th }}, 2020$, DOI: 10.13140/RG.2.2.11770.85449

Czudek, R. (2006). Wildlife issues and development prospects in West and Central Asia. FAO - Rome, Italy: Forestry Outlook Study for West and Central Asia (FOWECA), Retrieved October 20 ${ }^{\text {th }}, 2020$ from http:// www.fao.org/forestry/15797-071c0eecc9c1faee76357c4a4fa72dcla.pdf 
Dzagnidze, B. (2017). Fascinating Georgian Myths and Legends, Retrieved October $20^{\text {th }}, 2020$ from https:// theculturetrip.com/europe/georgia/articles/8-fascinating-georgian-myths-and-legends/

Kikvidze, Z. \& Tevzadze, G. (2015). Loss of traditional knowledge aggravates wolf-human conflict in Georgia (Caucasus) in the wake of socio-economic change. Ambio. 2015;44(5):452-457.

DOI:10.1007/s13280-014-0580-1

Leong, K., \& Decker, D. (2007). Identifying Capacity for Local Community Participation in Wildlife Management Planning. Ithaca, New York, USA, Retrieved October 20 2020 from https://www.nps.gov/vafo/ learn/management/upload/HumanDimensionsOfDeerMgmt.pdf

Lindpere, M. (2013). Pre-Christian beliefs and traditions in Georgia, Master thesis, University of Tartu, Faculty of Theology Retrieved October $20^{\text {th }}, 2020$ from https://dspace.ut.ee/bitstream/handle/10062/33530/MA Mirjam_\%20Lindpere2013.pdf?sequence=1\&isAllowed=y

Maanen, V., Goradze, I., Gavashelishvili, A. \& Goradze, R. (2001). Trapping and hunting of migratory raptors in western Georgia. Bird Conservation International, 11(2), 77-92. doi:10.1017/S095927090100017X

Malembo, M. (2011). Local Governance and Community Wildlife Management- A case study of Dutumi Selous Game Reserve-2011. Sokoine University of Agriculture, Dar es Salaam, Tanzania Retrieved October $20^{\text {th }}$, 2020 from https://acdn.tigurl.org/images/resources/tool/docs/3553.pdf

Maliasili, J. (2011). Wildlife for Communities in Tanzania: Taking stock of governance of wildlife by communities. Dar es Salaam, Tanzania Retrieved October $20^{\text {th }}, 2020$ from https://www.ucl.ac.uk/pima/docs/ reference/16_cwm_roundtable.pdf

Martín-Delgado, L.-M.; Rengifo-Gallego, J.-I.; Sánchez-Martín, J.-M. (2020). Hunting Tourism as a Possible Development Tool in Protected Areas of Extremadura, Spain. Land 9, 86, DOI: 10.3390/land9030086

Moqanaki, E., Jiménez, J., Vicente, L., \& Bensch, S. (2016). Are local perceptions of wildlife populations reliable? Lessons from the Caucasus. University of Cambridge, UK, Retrieved October $20^{\text {th }}, 2020$ from https:// www.researchgate.net/publication/299477966_Are_local_perceptions_of_wildlife_populations_reliable_Lessons_from_the_Caucasus

NASCO (2015). The state of community conservation in Namibia, A review of communal conservancies, community forests and other CBNRM initiatives (2015 Annual Report) NACSO, Windhoek, Namibia, Retrieved September $6^{\text {th }}, 2020$, Retrieved November $15^{\text {th }}, 2020$ from http://www.nacso.org.na/sites/default/ files/The\%20State\%20of\%20Community\%20Conservation\%20book\%202015.pdf

Roe, D., Seddon, N. \& Elliott, J. (2019). Biodiversity loss is a development issue: a rapid review of evidence. IIED Issue Paper. IIED, London, retrieved September $6^{\text {th }}, 2020$, Retrieved September $6^{\text {th }}$ from https://pubs.iied. org/pdfs/17636IIED.pdf

Sakal, W. \& Moyo, S. (2017). Socio-Economic Benefits of Community Participation in Wildlife Management in Zambia, Lusaka, Zambia, retrieved September $6^{\text {th }}, 2020$, from https://srwj.se/pdf/272017-0118.pdf

Sandor, A., Jansen, J., \& Vansteelant. W. (2017). Understanding hunters' habits and motivations for shooting raptors in the Batumi raptor-migration bottleneck, Southwest Georgia, Retrieved September $6^{\text {th }}, 2020$ from https://static1.squarespace.com/static/5b33912fb27e39bd89996b9d/t/5b3f2b45562fa72b1cec 1e85/1530866532985/Sandor_et_al-2017-Sandgrouse.pdf

Stone, M. (2006). Community-based natural resources management (CBNRM) and tourism: the Nata bird sanctuary project, central district, Botswana, Johannesburg, retrieved September $6^{\text {th }}, 2020$, Retrieved November $6^{\text {th }}, 2020$ from http://www.wings.issuelab.org/resources/13257/13257.pdf

Tuite, K. (2006). The meaning of Dæl. Symbolic and spatial associations of the south Caucasian goddess of game animals. In O'Neil, Catherine; Scoggin, Mary; Tuite, Kevin (eds.). Language, Culture and the Individual. A Tribute to Paul Friedrich (PDF). University of Montreal (pp. 165-188), Retrieved November 21 $1^{\text {st }}, 2019$ from http://www.mapageweb.umontreal.ca/tuitekj/caucasus/dal.htm

Tynnerson S. (2009). Community Based Wildlife Management - its Role in Conservation and Development, Bachelor's Thesis, Retrieved November 21 ${ }^{\text {st }}, 2019$ from http://www.diva-portal.org/smash/get/diva2:231657/ FULLTEXT01.pdf

UNECE (2019). State of Forests of the Caucasus and Central Asia, New York and Geneva, e-ISBN: 978-92-1363291-8 retrieved September $6^{\text {th }}, 2020$, from http://www.unece.org/fileadmin/DAM/timber/publications/sp-47-soccaf-en.pdf

Whande, W. (2007). Community Based Natural Resource Management in the Southern Africa Region: An Annotated Bibliography and General Overview of Literature, $1996-2004$, retrieved September $6^{\text {th }}, 2020$, fromhttps://www.tnrf.org/files/E-INFO_CBNRM_Bibliography_0.pdf 